\title{
Feasibility and success of HIV point-of-care testing in an emergency department in an urban Canadian setting
}

\author{
Marissa L Becker MD ${ }^{1,2}$, Laura H Thompson MSc ${ }^{1}$, Carla Pindera RN ${ }^{2,3}$, Natalie Bridger MD ${ }^{4}$, Carmen Lopez RN ${ }^{5}$, \\ Yoav Keynan $\mathrm{MD}^{2,6}$, Jared Bullard $\mathrm{MD}^{5,7}$, Paul Van Caseele $\mathrm{MD}^{5,7}$, Ken Kasper $\mathrm{MD}^{2,8}$
}

\begin{abstract}
ML Becker, LH Thompson, C Pindera, et al. Feasibility and success of HIV point-of-care testing in an emergency department in an urban Canadian setting. Can J Infect Dis Med Microbiol 2013;24(1):27-31.
\end{abstract}

BACKGROUND: Approximately 26\% of Canadians living with HIV are unaware of their status. Point-of-care (POC) HIV tests have been introduced to simplify and expand HIV testing.

OBJECTIVE: To evaluate the feasibility and acceptability of POC testing in an emergency department (ED) setting in Winnipeg, Manitoba. METHODS: A cross-sectional study of unselected adults presenting to the ED at the Health Sciences Centre Hospital (Winnipeg, Manitoba) was performed. Study procedures included pre- and post-test counselling, administration of the INSTI HIV-1/HIV-2 Antibody Test (bioLytical Laboratories, Canada) and a brief questionnaire. Venous blood samples were collected from participants for confirmatory testing on all reactive and indeterminate specimens.

RESULTS: In total, 501 adults participated in the study. The majority of participants were younger than 40 years of age, approximately onehalf $(48.5 \%)$ were women and $53 \%$ self-identified as Aboriginal. Nearly one-half $(49.1 \%)$ of the participants had undergone previous HIV testing, although $63 \%$ of these tests were performed more than a year earlier. A total of seven individuals tested reactive with the POC test, all of whom were confirmed positive using serological testing $(1.4 \%)$ and were linked to an HIV specialist within $24 \mathrm{~h}$. Nearly all of the participants (96\%) reported satisfaction with the test and believed it belonged in the ED (93\%).

CONCLUSIONS: Of the participants tested, 1.4\% tested reactive for $\mathrm{HIV}$, which is significantly higher than the reported prevalence in Manitoba and in other similar studies conducted in North America. Furthermore, all individuals were linked to timely care. The present study demonstrated that this particular busy tertiary care ED is an important and feasible location for HIV POC testing.
La faisabilité et le succès du test de dépistage du VIH au point de service au sein du département d'urgence d'un établissement canadien en milieu urbain

INTRODUCTION : Environ $26 \%$ des Canadiens qui sont atteints du VIH ne connaissent pas leur statut. Les tests du VIH au point de service (PDS) ont créés pour simplifier et généraliser le test du VIH.

OBJECTIF : Évaluer la faisabilité et l'acceptabilité du test au PDS au sein d'une urgence de Winnipeg, au Manitoba.

MÉTHODOLOGIE : Les chercheurs ont procédé à une étude transversale auprès d'adultes non sélectionnés qui se sont présentés à l'urgence du Health Sciences Centre Hospital de Winnipeg, au Manitoba. Pendant l'étude, les interventions incluaient des conseils avant et après le test, l'administration du test INSTI de recherche des anticorps anti-VIH-1/ VIH-2 (bioLytical Laboratories, Canada) et un bref questionnaire. Ils ont prélevé du sang veineux pour effectuer un test de confirmation sur tous les échantillons réactifs ou indéterminés.

RÉSULTATS : Au total, 501 adultes ont participé à l'étude. La majorité avaient moins de 40 ans, environ la moitié $(48,5 \%)$ étaient des femmes et $53 \%$ ont eux-mêmes précisé qu'ils étaient des Autochtones. Près de la moitié (49 \%) avaient déjà subi un test du VIH, mais $63 \%$ de ces tests avaient été exécutés plus d'un an auparavant. Au total, sept personnes étaient réactives au test au PDS, toutes confirmées comme positives au test sérologique $(1,4 \%)$ et ont été orientées vers un spécialiste du VIH dans les 24 heures. Presque tous les participants $(96 \%)$ se sont dits satisfaits du test et pensaient qu'il était caractéristique de l'urgence (93\%).

CONCLUSIONS : Sur les participants qui ont subi le dépistage, 1,4 \% était réactif au VIH, ce qui est considérablement plus élevé que la prévalence déclarée au Manitoba et dans d'autres études similaires d'Amérique du Nord. De plus, toutes les personnes ont été orientées rapidement vers des soins. La présente étude a démontré que cette urgence de soins tertiaires achalandée est un lieu important et faisable comme PDS pour effectuer le test du VIH.

Key Words: Emergency departments; HIV; Testing

Currently, there are approximately 65,000 Canadians living with HIV, and many new infections occur every year. It was estimated that in 2008, 2300 to 4300 new infections occurred in Canada, yet $26 \%$ of Canadians living with HIV are unaware of their status (1). In 2000, The Centers for Disease Control and Prevention in the United States (Atlanta, Georgia) estimated that $31 \%$ of persons accessing health care within the public sector system who tested HIV positive did not return to receive their results (2).

The prairie provinces of Canada are witnessing growing numbers of HIV-positive persons in care. The Manitoba HIV Program (MHP), which provides medical care to the majority (95\%) of HIV-positive patients in Manitoba, reported 102 new cases to care in 2010. Of these, $35 \%$ presented late to care with CD4 counts $<200$ cells $/ \mathrm{mL}$ (3). In untreated individuals, when the CD4 count is $<200$ cells $/ \mathrm{mL}$ the risk of opportunistic infections significantly increases. There is increasing evidence that the longer antiretroviral therapy is delayed, the poorer the patient outcome will be, with a decreased likelihood of immune recovery and life expectancy $(4,5)$. As such, current treatment guidelines have shifted to recommend initiation of antiretroviral therapy for persons with a CD4 count between 350 cells/mL and 500 cells/mL (6). In addition to these individual consequences of late presentation and delayed access to care, there are public health and health system implications as a reuslt of the increased cost associated with late presentation.

To reduce barriers to early diagnosis and increase access to timely care, simplified point-of-care (POC) rapid HIV tests have been introduced. In October 2005, Health Canada licensed a rapid HIV test, the INSTI HIV-1/HIV-2 Antibody Test (bioLytical Laboratories, Canada), for use by health care providers in the POC setting (7). In 2006, The Centers for Disease Control and Prevention indicated that all individuals 13 to 64 years of age should undergo routine HIV testing (8). Although current testing rates in Manitoba are increasing, only $6 \%$ of

${ }^{1}$ Centre for Global Public Health, University of Manitoba; ${ }^{2}$ Manitoba HIV Program; ${ }^{3}$ Nine Circles Community Health Centre, Winnipeg, Manitoba;

${ }^{4}$ Memorial University of Newfoundland, St John's, Newfoundland and Labrador; ${ }^{5}$ Department of Medical Microbiology; ${ }^{6}$ Department of Community

Health Sciences, University of Manitoba; ${ }^{7}$ Cadham Provincial Laboratory; ${ }^{8}$ Department of Medicine, University of Manitoba, Winnipeg, Manitoba

Correspondence: Dr Marissa L Becker, Center for Global Public Health, University of Manitoba, R070 Medical Rehabilitation Building,

771 McDermot Avenue, Winnipeg, Manitoba R3E 0T6. Telephone 204-272-3151, fax 204-789-3718, e-mail beckerm@cc.umanitoba.ca 
Manitobans 16 years of age and older were tested for HIV in 2010 (3). Recently, in Canada, two provinces have developed guidelines to implement HIV POC testing $(9,10)$, although, to date, POC testing has not been widely implemented.

Routine emergency department (ED) screening in high-volume and high-prevalence settings $(\geq 1 \%)$ has been recommended by the Society for Academic Emergency Medicine Public Health and Education Task Force (11). EDs often serve as a primary source of care for a large proportion of people believed to be at risk for HIV infection. Furthermore, it is believed that EDs are one of the most common sites for missed opportunities for diagnosing HIV (12). The need for higher rates of HIV testing in Manitoba remains unmet and rapid HIV POC testing in the ED setting presents an opportunity to offer testing to individuals who might otherwise not be tested. The present article described the results of a study evaluating the feasibility and acceptability of HIV POC testing in a Manitoba ED setting.

\section{METHODS}

\section{Study design}

A cross-sectional study of unselected adults presenting to the ED at the Health Sciences Centre (HSC) Hospital in Winnipeg (Manitoba) between October 2010 and September 2011 was conducted.

\section{Study setting and population}

The HSC Hospital is the major urban tertiary care hospital in Winnipeg and serves a large, underprivileged population of low socioeconomic status, who often have limited access to primary care. At the HSC Hosptial ED, there are approximately 27,000 visits per year from persons in the highest-risk age group (ie, 17 to 44 years of age) for HIV, which represents a large number of individuals for HIV screening.

All patients 18 years of age and older who presented to the HSC Hospital ED were eligible to participate in the study. Patients who selfidentified as HIV positive or who had altered mental status and were, therefore, deemed unable to provide consent, were excluded.

\section{Data collection}

ED staff, including both doctors and nurses, informed eligible ED patients of the study and, if patients indicated interest in learning more, they were approached by a research nurse trained in HIV testing and counselling. Following informed consent, pretest counselling was conducted, followed by administration of the INSTI HIV-1/HIV-2 Antibody Test at the bedside. Post-test counselling was subsequently conducted during the same visit and a brief questionnaire was completed, which collected basic sociodemographic information, the reason for the ED visit and HIV-related risk behaviours. Pre- and post-test counselling included teaching the participant about HIV, transmission modes, risk reductions, time frames for positivity after exposure and post-test follow-up, as required. Participants were also asked questions to assess their level of satisfaction, using a 5-point Likert scale, with the ED POC test (POCT), including their confidence in the test result and willingness to undergo future POC testing.

Fingerprick blood samples were collected for POC testing. A venous blood sample was collected from participants who had reactive and indeterminate specimens and were sent to the Cadham Provincial Laboratory (Winnipeg, Manitoba) for confirmatory enzyme immunoassay and western blot testing.

The present study was conducted between October 2010 and September 2011. Recruitment initially began in the triage area of the $\mathrm{ED}$, but due to service volume constraints, this process changed and the majority of the participants were recruited in the minor treatment area of the ED. Recruitment occured Monday through Friday between 08:00 and 17:00.

\section{Statistical analysis}

Data were entered into Access (Microsoft Corporation, USA) and statistical analysis was performed using STATA version 9.2 (StataCorp, USA). Risk groups were assigned to participant records by applying the Public Health Agency of Canada's risk hierarchy (13) to risk behaviours reported on questionnaires. Descriptive statistics using measures of central tendencies were reported. An exact binomial 95\% CI was calculated for every estimate using a Clopper-Pearson interval. Pearson $\chi^{2}$ tests were used to test for associations between having undergone a previous HIV test and sociodemographic characteristics, HIV-risk category, reason for ED attendance and test result.

\section{Ethical considerations}

Ethics approval was obtained from the Health Research Ethics Board of the University of Manitoba (Winnipeg, Manitoba).

\section{RESULTS}

The characteristics of the 501 study participants are presented in Table 1. Of the 501 participants, 55 (11.0\%) completed HIV POC testing but did not complete the post-test questionnaire assessing satisfaction. The primary reasons for noncompletion of the questionnaire included refusal and lack of time due to conflicting ED care. The majority of participants were younger than 40 years of age and approximately one-half $(48.5 \%)$ were women, and $53 \%$ of the participants self-identified as Aboriginal, including First Nations, Inuit and Metis. Heterosexual sex was the most commonly reported risk factor for transmission. However, a substantial proportion reported no risk factor, or being married or in a monogamous relationship.

Nearly one-half $(49.1 \%)$ of the participants had undergone a previous HIV test, although $63 \%$ of these tests were performed more than a year earlier; testing profiles are shown in Table 2. Women were significantly more likely to have undergone a previous HIV test, and higher rates of testing were also apparent among injection drug users and men who have sex with men. Individuals who reported no risk or being married or in a monogamous relationship were significantly less likely to have had a previous HIV test. Almost $40 \%$ of individuals did not have a family doctor but this had no significant association with whether they had received an HIV test previously.

A total of seven persons (1.4\%) tested reactive using the POCT, and all were confirmed positive using standard serological testing. The characteristics of participants who tested positive are shown in Table 3. The median age of the individuals who tested positive was 44 years (mean $[ \pm S D]$ age $43.3 \pm 14.6$ years). Of the seven individuals, five were men, four self-identified as Aboriginal, five had a regular family doctor and six had been seen by a doctor in the previous year. Of the seven individuals who had tested positive, six had previously had an HIV test, but the majority of these tests $(n=4)$ were conducted more than a year earlier. Three individuals who had tested positive had CD4 counts $>350$ cells $/ \mathrm{mL}$ and presented to the ED with non-HIV associated complaints (data not shown), and the remaing four individuals had CD4 counts $<200$ cells $/ \mathrm{mL}$ and presented with HIV-associated opportunistic infections including Pneumocystis pneumonia, Candida esophagitis and cryptococcal meningitis (data not shown). Within $24 \mathrm{~h}$ of the reactive test result, all seven individuals were linked with an HIV specialist and a program team for ongoing care. Four of the seven individuals were admitted to hospital for their presenting condition and were followed by the HIV team during their admission. These four individuals were seen in the HIV outpatient clinic within two weeks of their discharge from hospital. Two of the three individuals who were not admitted to hospital were seen in the HIV outpatient clinic within 10 days of their diagnosis. The third individual has been in contact by telephone with the HIV team but has not yet attended an outpatient appointment.

Nearly all (96\%) of the participants reported satisfaction with the test and $95.5 \%$ of participants were confident of the accuracy of the test. Furthermore, almost all of the participants believed the test belonged in the ED (93\%) and indicated that if they had the opportunity they would retest with POCT in the future (96\%). Overall, persons testing positive for HIV reported similar levels of satisfaction. 
TABLE 1

Profile of study participants

\begin{tabular}{|c|c|}
\hline Characteristic & $\begin{array}{c}\mathrm{n}(\%) \\
\text { (total sample size = 501) }\end{array}$ \\
\hline \multicolumn{2}{|l|}{ Age $^{\star}$, years } \\
\hline 18 to 24 & $104(20.8)$ \\
\hline 25 to 29 & $57(11.4)$ \\
\hline 30 to 34 & $59(11.8)$ \\
\hline 35 to 39 & $54(10.8)$ \\
\hline 40 to 44 & $58(11.6)$ \\
\hline 45 to 49 & $51(10.2)$ \\
\hline 50 to 54 & $52(10.4)$ \\
\hline$\geq 55$ & $65(13.0)$ \\
\hline \multicolumn{2}{|l|}{ Sex } \\
\hline Female & $243(48.5)$ \\
\hline Male & $257(51.3)$ \\
\hline Other & $1(0.2)$ \\
\hline \multicolumn{2}{|l|}{ Ethnicity } \\
\hline Aboriginal & $264(52.7)$ \\
\hline Caucasian & $199(39.7)$ \\
\hline Other & $38(7.6)$ \\
\hline \multicolumn{2}{|l|}{ Community of residence* } \\
\hline Outside of Winnipeg, Manitoba & $83(16.6)$ \\
\hline Winnipeg & $417(83.2)$ \\
\hline \multicolumn{2}{|l|}{ Has family doctor } \\
\hline No/don't know & $187(37.3)$ \\
\hline Yes & $314(62.7)$ \\
\hline \multicolumn{2}{|l|}{ Has seen doctor in the past year } \\
\hline No/don't know & $26(5.2)$ \\
\hline Yes & $475(94.8)$ \\
\hline \multicolumn{2}{|l|}{ HIV risk category } \\
\hline Heterosexual & $252(50.3)$ \\
\hline Married/monogamous & $64(12.7)$ \\
\hline Injection drug use & $39(7.7)$ \\
\hline Men who have sex with men & $9(1.8)$ \\
\hline No identifiable risk & $114(22.7)$ \\
\hline Occupational/blood and blood products & $6(1.4)$ \\
\hline Other & $17(3.4)$ \\
\hline
\end{tabular}

${ }^{*_{n}=500}$

\section{DISCUSSION}

Among participants in the present study, the HIV-positivity rate (1.4\%) was relatively high compared with the overall estimated HIV incidence in Manitoba of seven cases per 100,000 population (14) and the estimated Canadian HIV prevalence of $<0.5 \%$ (1). Furthermore, the proportion of HIV-positive individuals in the present study was substantially higher than similar studies conducted in other EDs. A recent review, which examined 11 studies evaluating nontargeted HIV screening in EDs, reported an overall prevalence of $0.52 \%$ (12). Given the high prevalence among participants in the present study, the results suggest that the ED is an important location for rapid POC HIV testing in Manitoba.

Of additional importance was that the present study, through its nontargeted approach, facilitated access to testing for individuals who may not have otherwise been tested for HIV. A large proportion of participants did not identify themselves as being at risk for HIV infection. This was reflected in their testing history; individuals who indicated that they were married or in a monogamous relationship were significantly less likely to have undergone an HIV test. In addition, three of the seven individuals who tested positive had CD4 counts $>350$ cells $/ \mathrm{mL}$ and presented for conditions unrelated to their HIV, suggesting that they may not have otherwise been tested if only risk-based screening was applied.
TABLE 2

Characteristics of participants with previous HIV tests

\begin{tabular}{|c|c|c|c|}
\hline \multirow[b]{2}{*}{ Characteristic } & \multicolumn{2}{|c|}{ Previous HIV test, n (\%) } & \multirow[b]{2}{*}{$\mathbf{P}$} \\
\hline & No/don't know & Yes & \\
\hline \multicolumn{4}{|l|}{ Age, years } \\
\hline 18 to 24 & $55(22.3)$ & $49(19.3)$ & 0.002 \\
\hline 25 to 29 & $27(10.9)$ & $30(11.8)$ & \\
\hline 30 to 34 & $19(7.7)$ & $40(15.7)$ & \\
\hline 35 to 39 & $19(7.7)$ & $35(13.8)$ & \\
\hline 40 to 44 & $31(12.6)$ & $27(10.6)$ & \\
\hline 45 to 49 & $26(10.5)$ & $25(9.8)$ & \\
\hline 50 to 54 & $25(10.1)$ & $27(10.6)$ & \\
\hline$\geq 55$ & $45(18.2)$ & $20(7.9)$ & \\
\hline \multicolumn{4}{|l|}{ Sex } \\
\hline Female & $92(37.4)$ & $151(59.4)$ & $<0.001$ \\
\hline Male & $154(62.6)$ & $103(40.6)$ & \\
\hline \multicolumn{4}{|l|}{ Ethnicity } \\
\hline Aboriginal & $115(46.6)$ & $149(58.7)$ & 0.0252 \\
\hline Caucasian & $111(44.9)$ & $88(34.6)$ & \\
\hline Other & $21(8.5)$ & $17(6.7)$ & \\
\hline \multicolumn{4}{|l|}{ Place of residence } \\
\hline $\begin{array}{l}\text { Outside of Winnipeg, } \\
\text { Manitoba }\end{array}$ & $45(18.2)$ & $38(15.0)$ & 0.3365 \\
\hline Winnipeg & $202(81.8)$ & $215(84.6)$ & \\
\hline \multicolumn{4}{|l|}{ Has family doctor } \\
\hline No/don't know & $96(38.9)$ & $91(35.8)$ & 0.4819 \\
\hline Yes & $151(61.1)$ & $163(64.2)$ & \\
\hline \multicolumn{4}{|c|}{ Has seen doctor in the past year } \\
\hline No/don't know & $14(5.7)$ & $12(4.7)$ & 0.634 \\
\hline Yes & $233(94.3)$ & $242(95.3)$ & \\
\hline \multicolumn{4}{|l|}{ Risk factor(s) } \\
\hline Heterosexual & $119(47.9)$ & $133(52.6)$ & $<0.001$ \\
\hline Injection drug use & $9(3.6)$ & $30(11.9)$ & \\
\hline MSM & $2(0.8)$ & $7(2.8)$ & \\
\hline Married/monogamous & $45(18.2)$ & $19(7.5)$ & \\
\hline No identifiable risk & $64(25.8)$ & $50(19.8)$ & \\
\hline Occupational/BBP & $3(1.2)$ & $3(1.2)$ & \\
\hline Other & $6(2.4)$ & $11(4.4)$ & \\
\hline
\end{tabular}

BBP Blood and blood products; MSM Men who have sex with men; NIR No identifiable risk

Furthermore, it is of tremendous significance that all the individuals who tested positive in our study were linked to timely care. Many argue that HIV screening alone is insufficient and that linkage to care should be considered as a more relevant marker (15). The present study demonstrated not only a high case detection rate, but also the ability to link all new cases of HIV to care within a short period of time, which has the potential to improve individual health outcomes.

The present study had several limitations. A convenience sampling of adults presenting to the ED was used and, as a result, may not be entirely representative of the entire population of Manitoba. In addition, the present analysis was a single-institution study; participants were only recruited from the HSC Hospital ED. We did not collect information on individuals who declined to participate in the study and, therefore, could not define how their sociodemographic characteristics may have differed from the study population. Furthermore, we could not determine the HIV prevalence of individuals who declined to participate in the study. There is some evidence to suggest that the rate of occult HIV infection is higher in individuals who decline routine ED HIV testing (16). Although considerable training was conducted with the ED staff regarding the eligibility criteria and the nontargeted design, there may have been some selection bias by the ED staff in screening potential participants. However, participants were recruited 
TABLE 3

Characteristics of participants with positive HIV test results

\begin{tabular}{ll}
\hline Characteristic & $\mathbf{n}(\%)$ \\
\hline Age, years & $1(14.3)$ \\
18 to 24 & $2(28.6)$ \\
30 to 34 & $1(14.3)$ \\
40 to 44 & $1(14.3)$ \\
45 to 49 & $2(28.6)$ \\
$\geq 55$ & \\
Sex & $2(28.6)$ \\
Female & $5(71.4)$ \\
Male & \\
Ethnicity & $4(57.1)$ \\
Aboriginal & $3(42.9)$ \\
Caucasian & \\
Community of residence & $1(14.3)$ \\
Outside of Winnipeg, Manitoba & $6(85.7)$ \\
Winnipeg & \\
Has family doctor & $2(28.6)$ \\
No/don't know & $5(71.4)$ \\
Yes & \\
Has seen doctor in the past year & $1(14.3)$ \\
No/don't know & $6(85.7)$ \\
Yes & \\
HIV risk category & $2(28.6)$ \\
Heterosexual & $1(14.3)$ \\
Injection drug use & $3(42.9)$ \\
Men who have sex with men & $1(14.3)$ \\
Other & \\
Year of last HIV test & $2(28.6)$ \\
Before 2010 & $4(57.1)$ \\
\hline &
\end{tabular}

throughout the week and at different times of the day and, therefore, we believe we captured a reasonable representation of the population attending the HSC Hospital ED. In fact, it is possible that the positivity rate may have been even higher if study nurses were available during nights and on weekends.

\section{REFERENCES}

1. Public Health Agency of Canada. HIV/AIDS Epi Update July 2010. Ottawa: Public Health Agency of Canada, 2010.

2. Centers for Disease Control and Prevention (CDC). Advancing HIV Prevention: New strategies for a changing epidemic United States, 2003. Morb Mortal Wkly Rep 2003;52:329-32.

3. Manitoba HIV Program. Manitoba HIV Program Report 2010. Winnipeg: Nine Circles Community Health Centre, 2011.

4. Sterne JA, May M, Costagliola D, et al. Timing of initiation of antiretroviral therapy in AIDS-free HIV-1-infected patients: A collaborative analysis of $18 \mathrm{HIV}$ cohort studies. Lancet 2009;373:1352-63.

5. Kitahata MM, Gange SJ, Abraham AG, et al. Effect of early versus deferred antiretroviral therapy for HIV on survival. N Engl J Med 2009;360:1815-26.

6. Thompson MA, Aberg JA, Cahn P, et al. Antiretroviral treatment of adult HIV infection: 2010 recommendations of the International AIDS Society-USA panel. JAMA 2010;304:321-33.

7. Public Health Agency of Canada. Point-of-Care HIV Testing Using Rapid HIV Test Kits: Guidance for Health-Care Professionals. CCDR 2007;33(S2):1-22.

8. Branson BM, Handsfield HH, Lampe MA, et al. Revised recommendations for HIV testing of adults, adolescents, and pregnant women in health-care settings.

Morb Mortal Recomm Rep 2006;55(RR-14):1-17.
There is growing recognition of the need to increase testing and to facilitate earlier diagnosis and linkage to care, given the challenges associated with late presentation, as outlined below. First, in terms of public health considerations, the longer patients are unaware of their HIV infection, or have untreated infection, the more opportunities there are for transmission. There has been considerable interest in the use of antiretroviral treatment for prevention of HIV by reducing viral load (17-20). In a recent clinical trial, early treatment resulted in a $96 \%$ relative reduction in sexual transmission of HIV among serodiscordant couples (21). Second, health care costs are inversely related to CD4 cell counts. The annual cost for a patient with a CD4 count $<200$ cells $/ \mathrm{mL}$ is approximately twice that of a patient whose counts are $>500$ cells $/ \mathrm{mL}$ (22). A Canadian study conservatively estimated that the annual excess cost due to late presentation of HIV was $\$ 9,723$ per case (22) and, more recently, it was demonstrated that significantly higher costs are incurred for those presenting to care with CD4 counts $<350$ cells/mL compared with individuals with higher CD4 counts, and that these higher costs were sustained beyond the first year of care for those individuals (23). Finally, late presentation is known to increase the risk of HIV-related complications and reduce life expectancy $(24,25)$. Life expectancy is strongly correlated with CD4 count at the start of therapy (26).

As such, it is important to expand testing options, including ensuring that HIV testing is offered in settings where high-risk individuals are likely to be seen (27). It is recognized that the ED is a primary place of care for persons with limited access to health care (28), low income populations (15) and individuals believed to be at high risk for HIV infection (29). As such, the ED has been recognized as an important setting for HIV testing, yet, despite this, HIV screening in the ED has not been systematically implemented in Canada. We believe the present study demonstrates the success and feasibility of conducting HIV POC testing in a busy tertiary care ED in Winnipeg. As other testing options, such as home-based HIV testing kits that have recently been approved by the United States Food and Drug Administration (30), become available in Canada, they will also need to be evaluated and offered as appropriate.

ACKNOWLEDGEMENTS/DISCLOSURES: The authors thank the many participants of this study. They also thank the POCT study team for all their hard work and dedication to this study. Finally, they thank the staff of the Emergency Room at the Health Sciences Centre for supporting this study with special thanks to Drs Palatnick and Sokal and Ms Laverne Sturtevant. This study was supported by a grant from Gilead Canada Gives.

9. Saskatchewan Ministry of Health. Guidelines for the Use of HIV Point of Care (POC) Test Kits in Saskatchewan: Saskatchewan Ministry of Health, 2012.

10. Communicable Disease Control BCfDC. Point of Care HIV Test Guidelines for Health Care Settings. Vancouver: BC Centre for Disease Control, 2011.

11. Babcock Irvin C, Wyer PC, Gerson LW. Preventive care in the emergency department, Part II: Clinical preventive services an emergency medicine evidence-based review. Society for Academic Emergency Medicine Public Health and Education Task Force Preventive Services Work Group. Acad Emerg Med 2000; 7:1042-54.

12. Haukoos JS. The impact of nontargeted HIV screening in emergency departments and the ongoing need for targeted strategies. Arch Intern Med. 2012;172:20-2.

13. Public Health Agency of Canada. HIV and AIDS in Canada, Surveillance Report to December 31, 2009. Ottawa: Public Health Agency of Canada, 2009.

14. Manitoba Health. Manitoba Health Statistical Update on HIV and AIDS. Report to December 31, 2011. Winnipeg: Manitoba Health, 2012. <www.gov.mb.ca/health/publichealth/surveillance/hivaids/ dec2011.pdf> (Accessed February 5, 2012).

15. Brown J, Shesser R, Simon G, et al. Routine HIV screening in the emergency department using the new US Centers for Disease 
Control and Prevention Guidelines: Results from a high-prevalence area. J Acquir Immune Defic Syndr 2007;46:395-401.

16. Czarnogorski M, Brown J, Lee V, et al. The prevalence of undiagnosed HIV infection in those who decline HIV screening in an urban emergency department. AIDS Res Treat 2011;2011:879065.

17. Quinn TC, Wawer MJ, Sewankambo N, et al. Viral load and heterosexual transmission of human immunodeficiency virus type 1 . Rakai Project Study Group. N Engl J Med 2000;342:921-9.

18. Del Romero J, Castilla J, Hernando V, Rodriguez C, Garcia S. Combined antiretroviral treatment and heterosexual transmission of HIV-1: Cross sectional and prospective cohort study. BMJ 2010;340:c2205.

19. Granich Ra, Crowley Sa, Vitoria Ma, et al. Highly active antiretroviral treatment as prevention of HIV transmission: Review of scientific evidence and update. Curr Opin HIV AIDS 2010;5:298-304.

20. Granich RM, Gilks CF, Dye C, De Cock KM, Williams BG. Universal voluntary HIV testing with immediate antiretroviral therapy as a strategy for elimination of HIV transmission: A mathematical model. Lancet 2009;373:48-57.

21. Cohen MS, Chen YQ, McCauley M, et al. Prevention of HIV-1 infection with early antiretroviral therapy. N Engl J Med 2011;365:493-505.

22. Krentz HB AM, Gill MJ. The high cost of medical care for patients who present late $(C D 4<200$ cells $/ \mu \mathrm{L})$ with HIV infection. HIV Medicine 2004;5:93-8.
23. Krentz HB, Gill MJ. The direct medical costs of late presentation $(<350 / \mathrm{mm})$ of HIV infection over a 15 -year period. AIDS Res Treat 2012;2012:757135.

24. Fisher M. Late diagnosis of HIV infection: Major consequences and missed opportunities. Curr Opin Inf Dis 2008;21:1-2.

25. May M, Gompels M, Delpech V, et al. Impact of late diagnosis and treatment on life expectancy in people with HIV-1:

UK Collaborative HIV Cohort (UK CHIC) Study. BMJ 2011;343:d6016.

26. Nakagawa F, Lodwick RK, Smith CJ, et al. Projected life expectancy of people with HIV according to timing of diagnosis. AIDS 2012;26:335-43.

27. Girardi E SC, Monforte A. Late diagnosis of HIV infection: Epidemiological features, consequences and strategies to encourage earlier testing. J Acquir Immune Defic Syndr 2007;46(Suppl 1):s3-s8.

28. Haukoos JS, Hopkins E, Byyny RL. Patient acceptance of rapid HIV testing practices in an urban emergency department: Assessment of the $2006 \mathrm{CDC}$ recommendations for HIV screening in health care settings. Ann Emerg Med 2008;51:303-9.

29. Torres M. Rapid HIV screening in the emergency department. Emerg Med Clin North Am 2010;28:369-80.

30. Food and Drug Administration. First Rapid Home-Use HIV Kit Approved for Self-Testing (2011). <www.fda.gov/downloads/ ForConsumers/ConsumerUpdates/UCM311690.pdf> (Accessed February 5, 2012). 


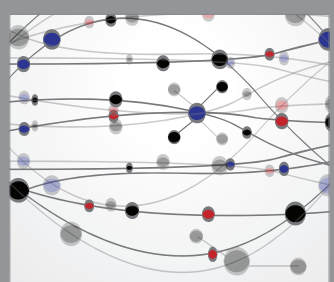

The Scientific World Journal
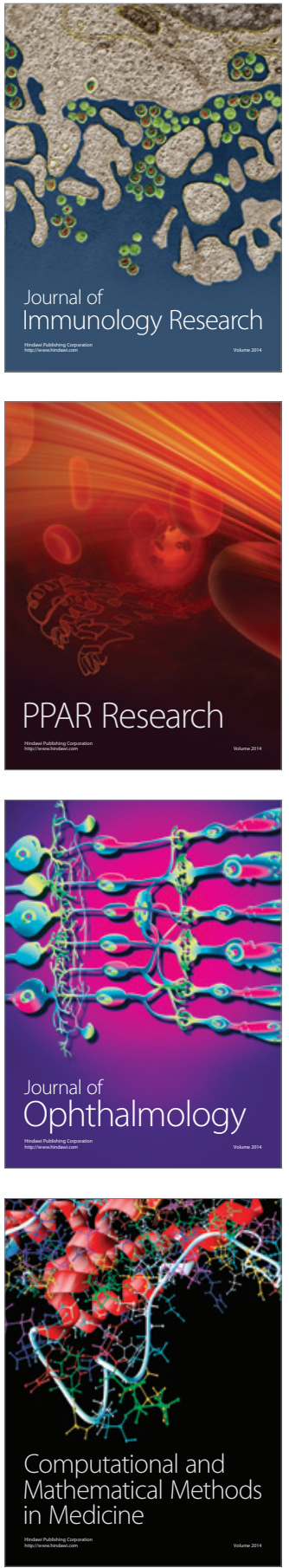

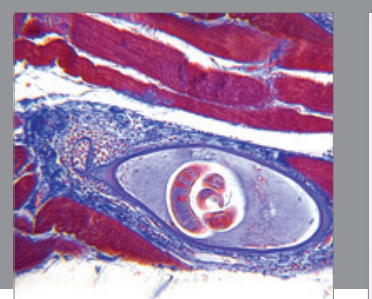

Gastroenterology Research and Practice

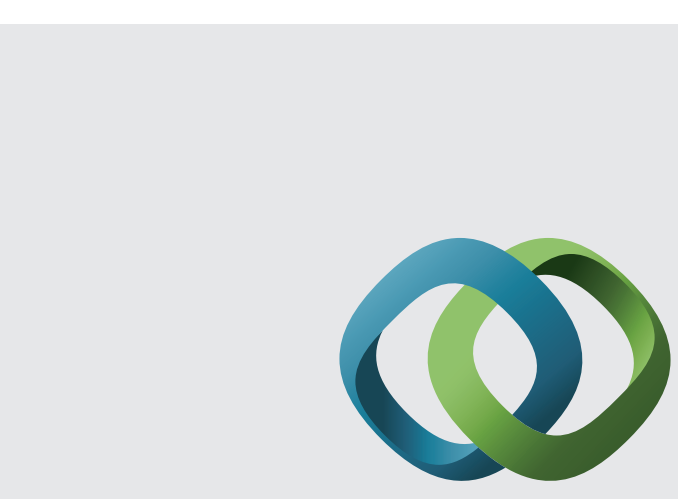

\section{Hindawi}

Submit your manuscripts at

http://www.hindawi.com
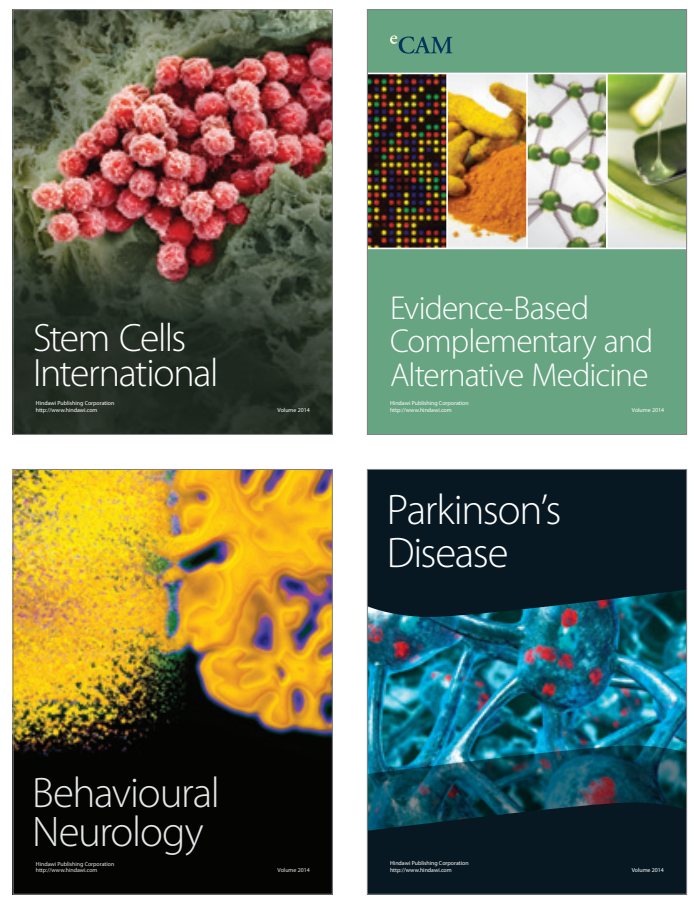
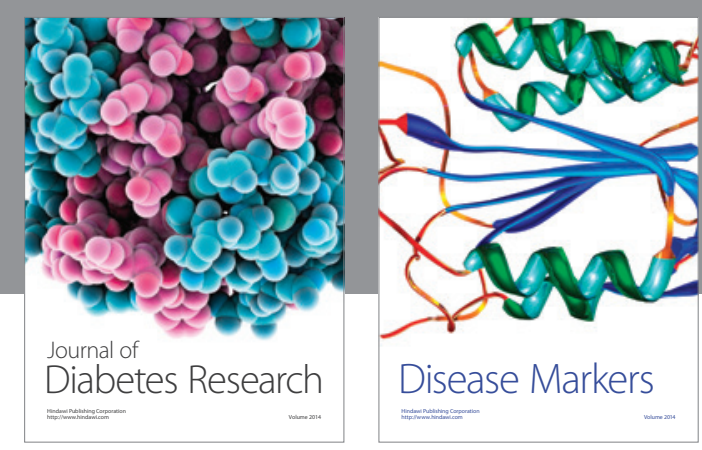

Disease Markers
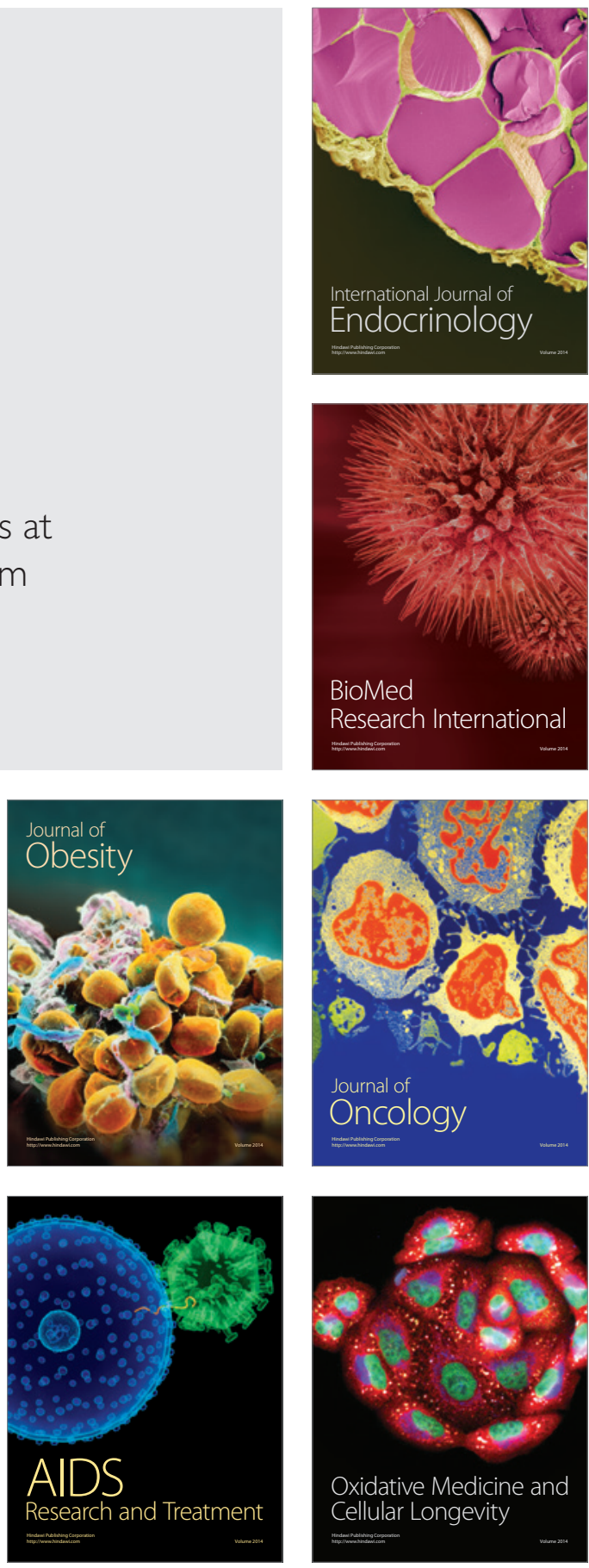